\title{
Effect of nutrient management on yield attributes and yield of milk thistle (Silybum marianum)
}

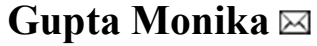

Received: 04.10.2019
Accepted: 09.01.2020

\begin{abstract}
The objective of this experiment is to determine the effect of nitrogen fertilizer dosses on the yield attributed and seed yield of silybum during rabi season 2018-19 towards development of new agrotechnology. For this purpose, different fertilizer dosses were evaluated and their responses were ascertained with respect to yield attributes and economic yield of silybum. The field experiment was conducted to study the effect of four treatments of different nitrogen doses viz., $T_{1}$ (control), $T_{2}$ (NPK@80:80:60/ha), $T_{3}$ (NPK@100:80:60/ha) and $T_{4}$ (NPK@ 120:80:60/ha kg NPK ha ${ }^{-1}$ ) with the spacing $50 * 50 \mathrm{~cm}$ row to row $\&$ plant to plant respectively with three replicates. The result showed significant influence of higher nitrogen doses $T_{4}$ (NPK@ 120:80:60/ha kg NPK ha $\mathrm{hr}^{-1}$ ) produced higher economic seed yield $\left(9.35 \mathrm{q} / \mathrm{ha}^{-1}\right)$ followed by $\mathrm{T}_{3}$

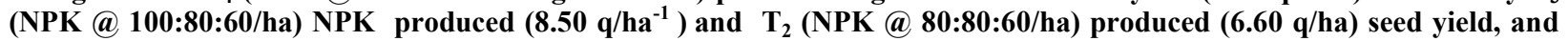
lowest seed yield $\left(2.55 \mathrm{q} / \mathrm{ha}\right.$ ) were recorded in $\mathrm{T}_{1}($ control) without fertilizer. The observation recorded revealed highest economic yield attribute like; plant height $(288.00 \mathrm{~cm})$, canopy $(102.1 * 99.2 \mathrm{~cm})$, number of leaf $(10)$ and highest seed yield $\left(9.35 \mathrm{q} / \mathrm{ha}\right.$ ) were recorded in $T_{4}$ application of NPK@ 120:80:60/ha $\mathrm{kg} \mathrm{NPK} \mathrm{ha}{ }^{-1}$ as compared to other treatments. Therefore, recommended application of NPK@120:80:60/ha $\mathrm{kg}^{\text {NPK ha }}{ }^{-1}$ is recommended for quality cultivation of silybum to get higher economic yield and return.
\end{abstract}

Keywords: agrotechnology, economic yield, quality cultivation, silybum (milk thistle), spacing

\section{Introduction}

Silybum marianum has other common names including Cardus marianus, milk thistle, (BSBI List 2007) blessed milkthistle, (USDA, 2015) Marian thistle, Mary thistle, Saint Mary's thistle, Mediterranean milk thistle, variegated thistle and Scotch thistle (though not to be confused with Onopordum acanthium).This species is an annual or biennial plant of the Asteraceae family. This fairly typical thistle has red to purple flowers and shiny pale green leaves with white veins. Milk thistles can grow to be 30 to $200 \mathrm{~cm}$ (12 to 79 in) tall, and have an overall conical shape (Singh et al., 1982). The approximate maximum base diameter is $160 \mathrm{~cm}$ (63 in) Milk thistle (Silybum marianum) is a thorny plant presenting decorative leaves with a white pattern of veins and purple flower heads. Traditional milk thistle extract is made from the seeds, which contain approximately 4$6 \%$ silymarin (Greenlee et al., 2007). The extract consists of about $65-80 \%$ silymarin (a flavonolignan complex) and 20-35\%

\section{Author's Address}

Sharda Nagar, Kanpur (U.P.), India

E-mail.: gupta_monika2005@yahoo.com fatty acids, including linoleic acid (Kroll, et al., 2007) Silymarin is a complex mixture of polyphenolic molecules, including seven closely related flavonolignans (silybin A, silybin B, isosilybin A, isosilybin B, silychristin, isosilychristin, silydianin) and one flavonoid (taxifolin) (Kroll et al., 2007). Silybinin, a semipurified fraction of silymarin, is primarily a mixture of two diastereo isomers, silybin $\mathrm{A}$ and silybin B, in a roughly $1: 1$ ratio .The plant originates from mountains of the Mediterranean region, where it forms scrub on a rocky base. Originally a native of Southern Europe through to Asia, it is now found throughout the world. The is a plant is a common weed of sub hilly regions in West Punjab and Frontier provinces of Pakistan. In India, its area of distribution is the foot hills and adjoining plains of Jammu and higher reaches of Kangra Valley in the north and a small tract between Coonoor and Ooty hills in Tamil Nadu. The plant generally occurs as roadside, railway tract weed, more frequently along nallahs and depressions overridden with moisture. Milk thistle has been used for a number of purposes including 
treatment of liver disease, prevention and treatment of cancer, and supportive treatment of poisoning from death cap mushrooms; however, clinical study results were described as heterogeneous and contradictory (Hogan et al., 2007). A 2007 Cochrane Review included eighteen randomized clinical trials which assessed milk thistle in 1088 patients with alcoholic and/or hepatitis $\mathrm{B}$ or $\mathrm{C}$ virus liver diseases. It questioned the beneficial effects and highlighted the lack of high-quality evidence. The review concluded that more good-quality, randomized clinical trials are needed (Rambaldi et al., 2007). Cancer Research UK say that milk thistle is promoted on the internet for its claimed ability to slow certain kinds of cancer, but that there is no good evidence in support of these claims (Milk thistle and liver cancer 2015) Milk thistle may appear to stimulate prolactin due to possibly estrogenic activity. Milk thistle based supplements have been measured to have the highest mycotoxin concentrations of up to $37 \mathrm{mg} / \mathrm{kg}$ when compared to various plant-based dietary supplements. Because of potassium nitrate content [citation needed], the plant has been found to be toxic to cattle and sheep. When potassium nitrate is eaten by ruminants, the bacteria in the animal's stomach breaks the chemical down, producing nitrite ions. Nitrite ions then combine with hemoglobin to produce methaemoglobin, blocking the transport of oxygen. The result form of oxygen deprivation (Tucker et al., 1961)

\section{Material and Methods Experimental sites:}

A field experiment was conducted at the research farm of CSIR-Central Institute of Medicinal and Aromatic Plants, Research Centre, Pantnagar (Udham Singh Nagar) Uttarakhand, India during karif season 2018. The experimental site is located between $29^{\circ} \mathrm{N}$ latitude and $79.38^{\circ} \mathrm{E}$ longitude and at an altitude of $243 \mathrm{~m}$ above mean sea level. The maximum temperature ranges between 35 to $45^{\circ} \mathrm{C}$, and minimum between 2 to $5{ }^{\circ} \mathrm{C}$. The experimental soil was sandy-loam in texture, neutral in reaction $(7.3 \mathrm{pH})$, medium in organic carbon $(0.55 \%)$, low in available nitrogen $\left(141 \mathrm{~kg} \mathrm{ha}^{-1}\right)$, and medium in available phosphorus $\left(14 \mathrm{~kg} \mathrm{ha}^{-1}\right)$ as well as in potassium (149 $\left.\mathrm{kg} \mathrm{ha}^{-1}\right)$. fertilizer used in 100:80:60 NPK.

\section{Transplanting method:}

Plant should be raised by sowing the seed proved more helpful for efficient cultural operation. 2-3 seeds are placed in loosened soil at the desired inter and intra row spacing and later covered with soil. One and a half to two $\mathrm{kg}$ seeds would be sufficient to stock one hectare of land. After the seed is germinated thinning is done, one healthy seedling is kept and rest are removed and utilized elsewhere to fill the gaps, though sowing in situ proved to be best. Transplanting method can also be used if the land to be stocked is not vacant at the time of sowing of seed. Germination studies showed a period of six months dormancy from June to November. Mature seeds collected during first week of May showed 20, 31, 78 and 80 percent germination in December, January, February and March, respectively. The sowing of the seeds should be started from November and can be extended up to January. Under cultivated conditions flowering commences in the second or third week or February and continues till the end of March. Thus it is advisable to sow the seed in early November, so that plant gets sufficient time for attaining optimum vegetative growth and see yield.

\section{Field preparation:}

It being a shallow rooted crop; does not require deep village. The preparation of land is usually not as fine as for other cultivated crops. One or two ploughing area, however, necessary. 10 tonnes / ha of well decomposed farm yard manure is applied before ploughing the field for getting a good growth and applied irrigation for sowing of seeds.

\section{Transplanting material:}

The crop is propagated by seeds

\section{Experimental design \& details of experiment:}

The field experiment was laid out in a Randomized Block Design with four treatments and three replications. The details of the treatments are represented in Table 1. The numerical data of all the components were subjected to analysis of variance (ANOVA) using randomized block design. Statistical analysis of data was done following standard procedures (Snedecor and Cochran, 1967). The field experiment laid out in randomized block design with four treatment viz. $\mathrm{T}_{1}$ (control), T 2 (NPK @ 80:80:60/ha), T3 (NPK@ 100:80:60/ha) and $\mathrm{T}_{4}$ (NPK@120:80:60/ha kg NPK ha ${ }^{-1}$ ) with the spacing $50 * 50 \mathrm{~cm}$ row to row \& plant to plant respectively with three replicates. The 
Table: 1. Effect of nutrient management on yield and yield attributes of Milk thistle (Silybum marianum)

\begin{tabular}{|c|c|c|c|c|c|c|}
\hline \multirow[t]{2}{*}{ Treatment } & \multirow[t]{2}{*}{ Plant height $(\mathrm{cm})$} & \multicolumn{2}{|c|}{ Canopy } & \multirow[t]{2}{*}{ No. of Leaf } & \multirow[t]{2}{*}{ No. of Flower } & \multirow[t]{2}{*}{ Seed Yield $(\mathrm{Q} / \mathrm{Ha})$} \\
\hline & & length & width & & & \\
\hline $\mathrm{T} 1$ & 160.0 & 82.1 & 58.1 & 5.0 & 8 & 2.55 \\
\hline $\mathrm{T} 2$ & 249.0 & 91.4 & 93.6 & 8.0 & 10 & 6.60 \\
\hline $\mathrm{T} 3$ & 283.0 & 97.3 & 94.9 & 9.0 & 24 & 8.50 \\
\hline $\mathrm{T} 4$ & 288.0 & 102.1 & 99.2 & 10 & 26 & 9.35 \\
\hline $\mathrm{S} \mathrm{Em}_{(0.05)}$ & 1.52 & 0.79 & 12.09 & 0.15 & 0.32 & 0.014 \\
\hline CD & 4.73 & 2.39 & 37.65 & 0.48 & 1.00 & 0.04 \\
\hline
\end{tabular}

$T_{1}$ (control), $T_{2}$ (NPK@80:80:60/ha), $T_{3}$ (NPK@100:80:60/ha) and $T_{4}\left(\mathrm{NPK} @ 120: 80: 60 / \mathrm{ha} \mathrm{kg} \mathrm{NPK} \mathrm{ha}^{-1}\right)$

full dose of $\mathrm{P} \& \mathrm{~K}$ and $1 / 3^{\text {rd }}$ dose of $\mathrm{N}$ were incorporated in field before last ploughing. Remaining $2 / 3^{\text {rd }}$ dose of $\mathrm{N}$ broadcast in filed at 25 and 45 DAS in two equal splits.

\section{Growth and yield analysis:}

The observations pertaining to plant height $(\mathrm{cm})$, no. of branches, canopy, no. of flower, seed yield were recorded at the time of harvest. The seed of Silybum were harvested in mature stage.

\section{Results and Discussion Plant height}

The data pertaining to the plant height of Silybum (Table 1) recorded during 2019. Transplanting of Silybum plant spacing $(50 * 50 \mathrm{~cm})$ resulted in significantly higher plant height after 150 DAS recorded in $\mathrm{T}_{4}(288.0 \mathrm{~cm})$ as compare to $\mathrm{T}_{3}(283.0$ $\mathrm{cm}), \mathrm{T}_{2}(249.0 \mathrm{~cm})$, and lowest were recorded in $\mathrm{T}_{1}(160.0 \mathrm{~cm})$ during 2018-2019. The similar trends of results obtained by Haban et al., 2009 and Kapahi et al., 1995.

\section{Canopy}

The detailed scrutiny of data presented in Table 1 revealed that the highest canopy length $(102.1 \mathrm{~cm})$ recorded in $T_{4}$ as compare to $T_{3}(97.3 \mathrm{~cm}), T_{2}$ ( $91.4 \mathrm{~cm})$ and the lowest canopy length recorded in $\mathrm{T}_{1}(82.1 \mathrm{~cm})$. The highest canopy width $(99.2 \mathrm{~cm})$ recorded in $\mathrm{T}_{4}$ as compare to $(94.9 \mathrm{~cm}) \mathrm{T}_{3}$ and $(93.6 \mathrm{~cm})$ in $T_{2}$. The lowest canopy width $(58.1 \mathrm{~cm})$ observed in $T_{1}$. The results obtained are in agreement with earlier studies of Haban et al., 2009 and Kapahi et al., 1995.

\section{Number of Leaf}

The data presented in Table 1 revealed that the significantly maximum no. of leaf were recorded in $\mathrm{T}_{4}$ ( 9.4) as compare to $\mathrm{T}_{3}(9.2), \mathrm{T}_{2}(7.6)$ and lowest no. of leaves observed in $\mathrm{T}_{1}$ (4.8). The Kapahi et al., (1995) also reported similar trends of results in their studies.

\section{Number of flower}

The results obtained are summarized in Table 1 revealed that the significantly maximum no. of flower 26 numbers recorded in $\mathrm{T}_{4}$ as compare to 24 no. of flowers in $\mathrm{T}_{3}$ and 10 no. of flowers in $\mathrm{T}_{2}$. The lowest 80 no. of flower was recorded in $\mathrm{T}_{1}$.

\section{Seed yield}

The data pertaining to seed yield of silybum crop is presented in table 1 . The significantly higher seed yield $9.35 \mathrm{q} \mathrm{ha}^{-1}$ was observed in $\mathrm{T}_{4}$ as compared to $8.50 \mathrm{q} \mathrm{ha}^{-1}$ in $\mathrm{T}_{3} 6.60 \mathrm{q} \mathrm{ha}^{-1}$ in $\mathrm{T}_{2}$. Lowest seed yield $2.55 \mathrm{q} \mathrm{ha}^{-1}$ was observed in $\mathrm{T}_{1}$. The similar trend of yield of silybum was also reported by Kapahi et. al. (1995) and the results obtained are in agreement with the earlier studies by the above researchers.

\section{Conclusion}

The observation recorded during the experiment revealed highest economic yield attribute like; plant height $(288.00 \mathrm{~cm})$, canopy $(102.1 * 99.2$ $\mathrm{cm})$, number of leaf (10) and highest seed yield $(9.35 \mathrm{q} / \mathrm{ha})$ were recorded in $\mathrm{T}_{4}$ application of NPK (a) 120:80:60/ha kg NPK ha ${ }^{-1}$ as compared to other treatments. Therefore, recommended application of NPK @ 120:80:60/ha kg NPK ha ${ }^{-1}$ is recommended for quality cultivation of silybum to get higher economic yield and return.

\section{Acknowledgments}

Authors are thankful to the Director, CSIR-Central Institute of Medicinal and Aromatic Plants, U.P., India for providing necessary facilities and encouragement. 


\section{Gupta Monika}

\section{References}

BSBI List. 2007. Botanical Society of Britain and Ireland. Archived from the original (xls) on 2015-01-25. Retrieved 2014-10-17.

Greenlee, H., Abascal, K., Yarnell, E. and Ladas, E. 2007. "Clinical Applications of Silybum marianum in Oncology". Integrative Cancer Therapies, 6 (2): 158-165.

Haban, M., Otepka1, P., Kobida1, L. and Habanova, M. 2009. Production and quality of milk thistle (Silybum marianum [L.] Gaertn.) cultivated in cultural conditions of warm agriclimatic macroregion. Hort. Sci. (PRAGUE), 36(2): 25-30.

Hogan, F.S., Krishnegowda, N.K., Mikhailova, M., Kahlenberg, M.S. 2007. Flavonoid, Silibinin, Inhibits Proliferation and Promotes Cell-Cycle Arrest of Human Colon Cancer. Journal of Surgical Research. 143 (1): 5865.

Kapahi, B.K., Srivastava, T.N., Balyan, S.S. and Sarin Y.K. 1995. Cultivation Of Silybum Marianum Gaertn: A Promising Medicinal Plant. Ancient Science of Life, 14(4): 240-244.
Kroll, D. J., Shaw, H.S., Oberlies, N.H. 2007. "Milk Thistle Nomenclature: Why It Matters in Cancer Research and Pharmacokinetic Studies". Integrative Cancer Therapies. 6(2): 110-119.

Rambaldi, A., Jacobs, B.P. and Gluud, C, 2007. Milk thistle for alcoholic and/or hepatitis B or C virus liver diseases. The Cochrane Database of Systematic Reviews (4): CD003620. doi:10.1002/14651858.CD003620.pub3.PMID 17943794.

Singh, J.P., Kapahi, B.K. and Sarin, Y.K. 1982. Ecology of Silybum marianum Garetn: A medicinal Plant. J. Econ. Tax. Bot., 3:665 - 668 .

Snedecor, G.M. and Cochran, W.G., 1967. Statistical Methods. Iowa State College Press, Ames, IA.

Tucker, J.M., Cordy, D.R. Berry, L.J. Harvey, W.A. and Fuller, T.C. 1961. Nitrate Poisoning in Livestock. Agricultural Publications, University of California. Pp 1-12.

USDA. 2015. "Silphium marianum". Natural Resources Conservation Service PLANTS Database. USDA. Retrieved 15 November 2015. 